\title{
SERMAYE ŞİRKETLERİNIN GENEL KURUL KARARLARININ HÜKÜMSÜZLÜĞÜ HAKKINDA YARGITAY 11. HUKUK DAİRESİNİN BİR KARARI ÜZERİNE ELEŞTİREL BİR YAKLAŞIM
}

\author{
Dr. Öğr. Üyesi A. Oğuzhan HACIÖMEROĞLU* \\ Arş. Gör. Kemalettin Ahmet AKSOY**
}

\begin{abstract}
ÖZET
Türk Ticaret Kanunu'nun öngördüğü kurucu şekli unsurları düzenleyen emredici hükümlere aykırı olarak alınan anonim ve limited şirket genel kurul kararları yoklukla malûldür. Bir genel kurul kararının yoklukla malûl olduğunun tespiti her zaman talep edilebilir. Yargitay 11. Hukuk Dairesi, T: 28.11.2017, E: 2016/6325 ve K: 2017/6651 sayılı kararında bir genel kurul kararının alındığından itibaren uzun süre geçtikten sonra yokluğunun tespitinin talep edilmesinin hakkın kötüye kullanılması yasağının ihlali anlamına geleceğine hükmetmiştir. İşbu çalışmamızda Yargıtay'ın mezkûr kararı eleştiri konusu yapılmıştır.

Anahtar Kelimeler: Yokluk, Butlan, Tespit Davası, Hakkın Kötüye Kullanılması Yasağı, Genel Kurul Kararı

Ankara Yıldırım Beyazıt Üniversitesi Hukuk Fakültesi, Ticaret Hukuku Anabilim Dalı, ohaciomeroglu@ybu.edu.tr/oguzhaciomeroglu@gmail.com, ORCID ID: 0000-0002-18384116.

** Ankara Yıldırım Beyazıt Üniversitesi Hukuk Fakültesi, Ticaret Hukuku Anabilim Dalı, kaaksoy@ybu.edu.tr, ORCID ID: 0000-0002-9239-7257, (Geliş Tarihi: 13.05.2020 - Kabul Tarihi: 05.07.2020).
\end{abstract}




\title{
A CRITICAL APPROACH TO THE DECISION OF THE 11TH CIVIL CHAMBER OF THE COURT CASSATION ON INVALIDITY OF GENERAL MEETING RESOLUTIONS OF CAPITAL COMPANIES
}

\begin{abstract}
Resolutions adopted by general meeting of joint stock companies and limited liability companies, which are against compulsory procedural provisions of Turkish Commercial Code, do not legally exist. There is no term of limitations to bring action for declaratory judgment in this case. The 11th Civil Chamber of the Court of Cassation ruled that the bringing this action after a long time passed after the resolution of the general meeting would be a violation of the prohibition of abuse of the rights (11th Civil Chamber of the Court of Cassation, Dated 28 November 2017, Numbered 2017/6651). In this study, the mentioned decision of the Court of Cassation is criticized.
\end{abstract}

Keywords: Nonexistence, Nullity, Action for Declaratory Judgement, Prohibition of Abuse of Rights, General Meeting Resolution 


\section{Gíriş}

Yargitay 11. Hukuk Dairesi'nin aşağıda özeti zikrolunan kararı limited şirket genel kurul kararlarının geçersizliğinin tespitine ilişkindir. Yüksek mahkeme kısaca bir genel kurul kararının yok hükmünde ${ }^{1}$ olduğunun tespitinin uzun süre dava edilmemesi halinde bu kararın artık geçerli hale geleceği sonucuna varmıştır². Çalışmamız bu sonucun hukuken doğru olup olmadığı ile ilgilidir. $\mathrm{Bu}$ sebeple çalışmamızda limited şirket genel kurul kararlarının hükümsüzlük halleri ve bunlara ilişkin davaların ne kadar süre içerisinde açılması gerektiği üzerinde durulacak ve akabinde söz konusu kararın yerindeliği üzerinde kısa bir değerlendirme yapılacaktır. Çalışmamızın kapsamını gereksiz yere arttırmamak adına limited şirketlerde genel kurul toplantısının yapılma sürecinin nasıl olduğu ve kararların ne şekilde alındığı üzerinde durulmayacaktır. Fakat eleştiri konusu yaptığımız Yargıtay kararı çağrısız genel kurul toplantısında alınan bir karara ilişkin olduğu için çağrısız genel kurul hakkında kısa bir bilgi verilecektir.

Her ne kadar söz konusu Yargitay kararına konu olan genel kurul kararları limited şirkete ilişkin olsa da yaptığımız değerlendirme anonim şirketler için de geçerlidir. Bununla birlikte dava konusu olan genel kurul kararları 6762 sayılı (mülga) Türk Ticaret Kanunu³ döneminde alındığı için çalışmamızda mesele hem mülga hem de şu an yürürlükte olan 6102 sayılı Türk Ticaret Kanunu ${ }^{4}$ açısından irdelenecektir.

1 Her ne kadar mezkûr kararda yüksek mahkeme "batıl” ifadesini kullanmış olsa da aşağıda yapacağımız izahattan da istidlal olunacağı üzere söz konusu genel kurul kararı aslında "yok" hükmündedir.

2 Yargıtay 11. H.D.'nin son dönemde ve aynı yönde verdiği diğer kararları için bkz. Yargıtay 11. Hukuk Dairesi, E: 2016/12761, K: 2018/1791, T: 08.03.2018 ve E: 2019/3, K: 2019/7182, T: 13.11.2019. (https://karararama.yargitay.gov.tr/YargitayBilgiBankasiIstemciWeb/) s.e.t.: 25.03 .2020 .

3 R.G. T. 9/7/1956, S. 9353.

4 R.G. T. $14 / 2 / 2011$, S. 27846. 


\section{HUKUKİ PROBLEM}

A. C. adlı şahıs, C. O. A. S. Ltd. Şti'nin \%45 oranda pay sahibidir. G. C. adlı şahıs ise aynı şirketin hem ortağı hem de müdürüdür. Söz konusu şirkette 23.12.1995 tarihinden itibaren farklı tarihlerde ve çağrısız olarak gerçekleştirilen genel kurullarda sermaye artırım kararları alınmıştır. Bu genel kurulların hiçbirine A.C. katılmamıştır. Fakat G.C., bu genel kurul kararlarının altına A.C. sanki toplantıya katılmış gibi göstererek onun yerine (sahte) imza atmıştır. G.C.'nin sahte imzalarla aldığı sermaye artırımı kararları neticesinde A.C.'nin şirketteki \%45’lik pay oranı \%0,1'e düşmüştür. Bunun üzerine A.C., toplantı çağrısı yapılmadan ve imzası taklit edilmek suretiyle sahte imzalarla alınan sermaye artırımına ilişkin genel kurul kararlarının "mutlak butlanla batıl ve yok hükmünde olduğunun tespitiyle iptallerini" ve davalı şirkette \%45 oranında pay sahibi olduğunun tespitini 31.12.2012 tarihinde açtığ 1 dava ile talep etmiştir.

Davalı taraf ise, davacının 17 yıl sonra bu davayı açmış olmasının hakkın kötüye kullanılması niteliğinde olduğunu ve üç aylık iptal davası açma süresinin geçmiş olduğunu ileri sürerek davanın reddini istemiştir.

İlk derece mahkemesi "davacının kendi kabulünde olan sermaye artı̧̧ kararına göre pay oranının \%40 olduğunu, bundan sonra yapılan davaya konu sermaye artış kararlarında davacı adına atılan imzaların davacının eli ürünü olmadığını, bu imzaların bilirkişi incelemesi sonucu sahte olduklarının anlaşıldiğını, davaya konu sermaye artış kararlarının ana sözleşme değişikliğine ilişkin olup 6762 sayılı Türk Ticaret Kanunu’nun 513’üncü maddesinin birinci fikrasında öngörülen nisapla alınmadiğından yok hükmünde olduğunu, sermaye ödemesinin davacı tarafça yapıldı̆̆ının kesin olarak kanıtlanamadiğından bu durumun davacının yapılan işlemlere sonradan onay verdiği șeklinde yorumlanamayacağını, davacının dava hakkını bilerek kötüye kullandiğına dair savunmayı kanıtlayan somut bir delilin gösterilmediğini, sadece uzun süre geçmiş olmasının davacının dava hakkını

\footnotetext{
Her ne kadar söz konusu kalıbın teorik açıdan hatalı olduğunun farkında olsak da çalışma konumuzu teşkil eden Yargıtay kararında davacının talebinin bu yönde olduğu belirtildiği için aslına sadık kalmak açısından biz de çalışmamızın en azından bu kısmında mezkûr kalıbı aynen kullanmayı tercih ettik.
} 
kötüye kullandığı sonucunu ortaya koymayacağını belirterek, 12/11/1997, 17/09/1998, 28/09/2001, 17/06/2004, 23/05/2005, 14/12/2009, 02/02/2010 ve 28/11/2011 tarihli sermaye artış kararlarının yokluğuna ve davacının davalı şirkette \%40 pay sahibi olduğunun tespitine" karar vermiştir.

Karar davalı tarafından temyiz edilmiştir. Yargıtay 11. Hukuk Dairesi "butlanın ileri sürülmesinin dürüstlük kuralı çerçevesinde mümkün olduğunu, hakkın kötüye kullanılması hallerinin neler olduğunun her davada somut olayın şartlarına göre belirlenmesi gerektiğini ve geçen sürenin dikkate alınarak genel kurul kararlarının butlanının ileri sürülmesinin dürüstlük kurallarına ve hakkın kötüye kullanılması yasağına aykırı niteliği haiz olup olmadığının değerlendirilmesi gerekirken yazıl gerekçeyle hüküm tesisinin doğru olmaması sebebiyle" ilk derece mahkemesinin kararını davalı lehine oyçokluğuyla bozmuştur $^{6}$. Bu üzerine davacı karar düzeltme talebinde bulunmuştur. Yargitay 11. Hukuk Dairesi, karar düzeltme talebini de oyçokluğuyla reddederek aynı yönde karar vermiştir? ${ }^{7}$

\section{II. ÇAĞRISIZ GENEL KURUL}

Anonim ve limited şirket genel kurul toplantıları, davetin belli bir prosedüre tâbi tutulup tutulmadığına göre çağrılı ve çağrısız genel kurul toplantısı şeklinde ikiye ayrılır ${ }^{8}$. Hem 6762 sayılı Türk Ticaret Kanunu'nda hem de 6102 sayılı Türk Ticaret Kanunu'nda ${ }^{9}$ anonim ve limited şirketin genel

6 Yargitay 11. Hukuk Dairesi, E: 2016/6325, K: 2017/6651, T: 28.11.2017.

(https://karararama.yargitay.gov.tr/YargitayBilgiBankasiIstemciWeb/) s.e.t.: 24.03.2020. Yargitay 11. Hukuk Dairesi, E: 2018/1328, K: 2019/6943, T: 07.11.2019.

(https://karararama.yargitay.gov.tr/YargitayBilgiBankasiIstemciWeb/) s.e.t.: 24.03.2020.

8 Orbay Ortaç, Nurdan/ Al Kılıç, Şengül (2018) Anonim Şirket Yönetim Kurulu Üyelerinin ve Murahhasların Genel Kurula Katılması, TFM, 2018, C. 4, S. 2, s. 222.

9 Aslında limited şirket genel kurulu bakımından 6102 sayılı Türk Ticaret Kanunu'nda 6762 sayılı Türk Ticaret Kanunu'na nazaran önemli değişiklikler yapıldığ söylenebilir. 6762 sayılı kanunda limited şirkette ortak sayısına göre bir ayrım yapılmakta ve ortak sayısı 20'den fazla olan limited şirketlerde anonim şirket genel kuruluna ilişkin hükümlerin limited şirkete de uygulanacağı esası benimsenmekte idi. 6102 sayılı kanunda ise ortak sayısına göre bir ayrım yapılması anlayışı terk edilmiş ve bazı konular hariç anonim şirket genel kuruluna ilişkin hükümlere atıf yapılmıştır. Söz konusu kanunun 617’nci maddesinin 
kurul toplantılarına ortakları davet belli başlı kurallara ${ }^{10}$ bağlanmıştır ${ }^{11}$. Kanun koyucu genel kurul toplantılarına davet şekillerinin az ortaklı şirketler açısından pratik olmayacağı düşüncesiyle her iki kanunda da çağrısız genel kurul toplantısını düzenleme ihtiyacını hissetmiştir. 6762 sayılı kanunun 370'inci maddesine göre anonim şirketlerde bütün payların sahip veya temsilcileri, aralarından biri itirazda bulunmadığı takdirde genel kurul toplantılarına dair olan diğer hükümler saklı kalmak şartıyla toplantıya davet hakkındaki merasime riayet etmeksizin de genel kurul olarak toplanabilirler. Mezkûr hükme benzer bir düzenlemenin aynı kanunun 538'inci maddesinin beşinci fikrasında limited şirketler için de ihdas edildiği görülmektedir. Söz konusu maddeye göre bütün ortaklar; aralarından biri itirazda bulunmadığ

üçüncü fikrası bunun en iyi örneğidir (Erdoğan, Abdullah (2013) "6102 sayılı Türk Ticaret Kanunu'nun Limited Şirket Genel Kuruluna İlişkin Hükümlerinin Değerlendirilmesi”, GÜHFD, C.XVII, Y.2013, S.3, s. 40). Filhakika mezkûr düzenlemeye göre toplantıya çağrı, azlığın çağrı ve öneri hakkı, gündem, öneriler, çağrısız genel kurul, hazırlık önlemleri, tutanak, yetkisiz katılma konularında anonim şirketlere ilişkin hükümler, Bakanlık temsilcisine ilişkin olanlar hariç, kıyas yoluyla limited şirkete de uygulanır.

Bu konu hakkında ayrıntılı bilgi için bkz. Narbay, Şafak (2006) “TTK Tasarısı'nda Anonim Ortaklık Genel Kurulunu Toplantıya Davete Yetkili ve Görevli Olanlara İlişkin Hükümlerin Değerlendirilmesi”, HPD 2006, S. 7, s. 168 vd.

6762 sayılı Türk Ticaret Kanunu'nun 368'inci maddesine göre anonim şirket genel kurul toplantısına davet, esas sözleşmede gösterilen şekil ve surette ve her halde Türkiye Ticaret Sicil Gazetesi'nde ilan ve toplantı günleri dahi olmamak üzere, toplantı vaktinden en az iki hafta önce yapılmalıdır. Senetleri nama yazılı olan pay sahipleriyle önceden şirkete bir hisse senedi tevdi ederek ikametgâhını bildiren pay sahiplerine, taahhütlü mektup gönderilmesi suretiyle de toplantı günü bildirilir. Aynı kanunun 538'inci maddesinin dördüncü fıkrasına göre limited şirket genel kurul toplantısına ortaklar şirket sözleşmesinde gösterilen şekilde ve eğer sözleşmede bu hususta hüküm yoksa taahhütlü mektupla davet edilir ve bu davet toplantıdan en az beş gün önce yapılır.

6102 sayılı Türk Ticaret Kanunu'nun 414'üncü maddesinin birinci fikrasina göre ise anonim şirkette genel kurul toplantıya, esas sözleşmede gösterilen şekilde, şirketin internet sitesinde ve Türkiye Ticaret Sicili Gazetesi'nde yayımlanan ilanla çağrılır. Bu çağrı, ilan ve toplantı günleri hariç olmak üzere, toplantı tarihinden en az iki hafta önce yapılır. Pay defterinde yazılı pay sahipleriyle önceden şirkete pay senedi veya pay sahipliğini ispatlayıcı belge vererek adreslerini bildiren pay sahiplerine, toplantı günü ile gündem ve ilanın çıktığ 1 veya çıkacağı gazeteler, iadeli taahhütlü mektupla bildirilir. Mezkûr düzenleme aynı kanunun 617'nci maddesinin üçüncü fikrasının yaptığı yollama gereği limited şirket genel kurul toplantılarına davet için de uygulanır. 
takdirde toplantıya çağırma hakkındaki merasime riayet etmeksizin de genel kurul halinde toplanabilirler. Böyle bir toplantıda bütün ortaklar hazır olmak şartıyla, genel kurulun yetkisine dâhil olan hususlar müzakere edilerek karara bağlanabilir. 6102 sayılı kanunun $416^{\prime} \mathrm{nc1}$ maddesine göre ise anonim şirketlerde bütün payların sahipleri veya temsilcileri, aralarından biri itirazda bulunmadığı takdirde, çağrıya ilişkin usule uyulmaksızın, genel kurul olarak toplanabilirler ve bu toplantı nisabı var olduğu sürece karar alabilirler. Kanun koyucu 6102 sayılı kanunda limited şirketlerde çağrısız genel kurul toplantısını 617'nci maddenin üçüncü fikrasında 416'ncı maddeye yollama yaparak düzenlemiştir.

Hem mülga hem de şu an yürürlükte olan Türk Ticaret Kanunu'nun yukarıda bahsi geçen maddelerine bakıldığında anonim ve limited şirketlerde çağrısız genel kurul toplantısının yapılmasının belli şartlara bağlandığı görülmektedir. Bu şartlar; bütün pay sahipleri veya temsilcilerinin toplantıda hazır bulunması ve hiçbirinin toplantıya itirazda bulunmamasıdır. İtirazın doğrudan yapılacak olan çağrısız genel kurul toplantısına veya karar alınmasına ilişkin olması gerekir ${ }^{12}$. Her iki kanunda da çağrısız genel kurul toplantısı için toplantı yetersayısı bütün pay sahipleri veya temsilcilerinin hazır bulunması şeklinde belirlenmiştir. 6102 sayılı Türk Ticaret Kanunu, bu konu bakımından 6762 sayılı kanundan farklı olarak, çağrısız genel kurulda geçerli bir karar alınabilmesinin söz konusu toplantı yetersayısının devamlılığına bağlı olduğunu açıklığa kavuşturmuştur. Söz konusu iki şartın, çağrısız genel kurul toplantısında alınacak kararların kurucu unsuru olduğu kabul edilmelidir. Dolayısıyla herhangi bir pay sahibinin veya temsilcisinin toplantıda hazır bulunmaması ya da toplantıyı terk etmesi veyahut toplantıya itiraz etmesi halinde çağrısız genel kurul mevcut değildir ve artık karar

12 Poroy, Reha/Tekinalp, Ünal/Camoğlu, Ersin (2014) Ortaklıklar Hukuku C. 1, 13. Baskı, İstanbul, Vedat, s. 477-478, N. 669; Moroğlu, Erdoğan (2017) Anonim Ortaklıkta Genel Kurul Kararlarının Hükümsüzlüğü, 8. Baskı, İstanbul, Onikilevha, s. 120. Saka’ya göre ise itirazın, genel kurulun çağrı yöntemine yönelik olması gerekir. Yazar, gündeme yapılan itirazların toplantıya engel teşkil etmeyeceğini savunmaktadır (Saka, Zafer (2004) Anonim Ortaklıklarda Genel Kurul, İstanbul, Vedat, s. 110). 
alınamaz. Şayet söz konusu şartların eksikliğine rağmen karar alınırsa, bu karar yoklukla malûldür ${ }^{13}$.

\section{GENEL KURUL KARARLARININ HÜKÜMSÜZLÜK HALLERİ}

Hukuki işlemler, sözleşme ve karar şeklinde ikiye ayrılır. Her iki hukuki işlemin de hükümsüz olması mümkündür. Bu hükümsüzlük hali baştan itibaren olabileceği gibi daha sonra da olabilir. Karar şeklindeki bir hukuki işlemin hükümsüz olması, onun yöneldiği hukuki sonucu gerçekleştirme gücünün olmadığı anlamına gelir ${ }^{14}$.

Limited şirket genel kurul kararlarının hükümsüzlük halleri, yokluk, butlan ve iptal edilebilirlik şeklinde karşımıza çıkar ${ }^{15}$.

\section{A. YOKLUK}

Bir hukuki işlemin kurucu unsurlarının eksik olması hâlinde, o işlem yok hükmündedir ${ }^{16}$. Yok hükmünde olan işlemler varlık kazanamazlar ve bu

13 Moroğlu, s. 118 vd. Bkz. Yargitay 11. Hukuk Dairesi, E: 2016/8889, K: 2017/6204, T: 15.11.2017 (https://karararama.yargitay.gov.tr/YargitayBilgiBankasiIstemciWeb/) s.e.t.: 24.03.2020.

14 Tekinay, Selahattin Sulhi/Akman, Sermet /Burcuoğlu, Haluk/Altop, Atilla (1993) Borçlar Hukuku 7. Bası, İstanbul, s. 374; Oğuzman, M. Kemal (1985) Medeni Hukuk Dersleri, 5. bası, İstanbul, s. 138; Tekinay, Selahattin Sulhi (1984) Medeni Hukuka Giriş Dersleri, 4. Bası, İstanbul, s. 117; Önder, M. Fahrettin (2005) "Yargıtay Kararları Açısından Limited Şirket Genel Kurul Kararlarının Hükümsüzlügü̈, DEÜHFD, C. 7, S. 1, s. 107.

Bkz. Yargitay Hukuk Genel Kurulu, E: 2013/11-1048, K: 2014/430, T: 02.04.2014 (https://karararama.yargitay.gov.tr/YargitayBilgiBankasiIstemciWeb/) s.e.t.: 24.03.2020.

Edis, Seyfullah (1979) Medeni Hukuka Giriş ve Başlangıç Hükümleri, Ankara, Ankara Üniversitesi, s. 147; Kocayusupaşaoğlu, Necip/Hatemi, Hüseyin/Serozan, Rona / Arpacı, Abdulkadir (2014) Borçlar Hukuku C.1, Genel Bölüm, Borçlar Hukukuna Giriş, Hukuki İşlem, Sözleşme, 6. Baskı, İstanbul, Filiz, $\$ 43$, N. 1; Oğuzman, M. Kemal / Barlas, Nami (2016) Medeni Hukuk Giriş Kaynaklar Temel Kavramlar, 22. Bası, İstanbul, Vedat, N. 742; Bahtiyar, Mehmet (2020) Ortaklıklar Hukuku, 14. Baskı, İstanbul, Beta, s. 196; Antalya, Gökhan (2015) Borçlar Hukuku Genel Hükümler, C.1, Temel Kavramlar, Sözleşmeden Doğan Borç İlişkileri, İstanbul, Legal, s. 127. 
sebeple amaçlanan hukuki ilişki de kurulamaz ${ }^{17}$. Bir hukukî işlemin kurucu unsuru irade beyanıdır ${ }^{18}$. Dolayısıyla irade beyanının bulunmadığı hâllerde artık o hukukî işlemin var olmadığı kabul edilmelidir ${ }^{19}$. Genel kurul kararlarının da kurucu unsurları vardır. Bir kararın alınış sürecinde eğer bu kurucu unsurlar eksikse o karar yok hükmündedir ${ }^{20}$.

Yokluk mahkeme tarafından re’sen göz önüne alındığı gibi, menfaat sahipleri tarafından da süresiz olarak ileri sürülebilir ${ }^{21}$. Hatta doktrinde, kurucu unsurlarının eksikliği hâlinde artık bir sözleşmenin varlığından bahsedilemeyeceğini, dolayısıyla var olmayan bir sözleşmenin hükümsüzlüğünden bile söz edilemeyeceğini ifade eden görüşler yer almaktadir ${ }^{22}$.

Yukarıda da ifade ettiğimiz üzere bir genel kurul kararının kurucu unsurları eksikse o karar yok hükmündedir. Buna rağmen ne 6762 sayılı ne de 6102 sayılı Türk Ticaret Kanunu'nda limited şirket genel kurul kararlarının yokluğuna ilişkin herhangi bir düzenleme yer almaktadır. Filhakika Türk hukuk sistemi içinde özü itibariyle yokluk yaptırımını doğrudan düzenleyen bir hükme rastlamak da mümkün değildir ${ }^{23}$.

17 Oğuzman / Barlas, N. 742; Kırca, İsmail/Şehirali Çelik, Feyzan Hayal/Manavgat, Çağlar (2016) Anonim Şirketler Hukuku C. 2/2, Genel Kurul Kararlarının Hükümsüzlüğü, Ankara, Banka ve Ticaret Hukuku Araştırmaları Ensitüsü, s. 4; Tekil, Fahiman (1981) Borçlar Hukuku, İstanbul, s. 93; Eren, Fikret (2019) Borçlar Hukuku Genel Hükümler, 24. Baskı, Ankara, Yetkin, s. 406; Oğuzman, M. Kemal /Öz, Turgut (2019) Borçlar Hukuku Genel Hükümler, C.1, 17. Bası, İstanbul, Vedat, s. 130.

Eren, s. 348; Kırca (Şehirali Çelik, Feyzan Hayal/Manavgat, Çağlar), s. 4.

Bir hukuki işleme irade beyanına ek olarak kurucu unsurların eklenmesi mümkündür. Örneğin, kişi evlenme konusundaki iradesini, evlendirme ile yetkili memur dışında başka bir kimsenin huzurunda açıklarsa söz konusu evlilik yok hükmünde olacaktır. (Oğuzman/Barlas, N. 744). Moroğlu, s. 77 vd.; Önder, s. 107. iptaline ilişkin 83'üncü maddesinin 3'üncü fikrasıdır. Söz konusu düzenlemede, "genel kurul kararlarının yok veya mutlak butlanla hükümsüz sayıldığı durumlar saklıdır" ifadesi 
Şirket genel kurul kararlarının yokluğu, genel hükümlerden kaynaklanabileceği gibi şirketlere ilişkin özel hükümlerden de kaynaklanabilirr ${ }^{24}$. Doktrinde, şirketler hukuku bağlamında yokluğun, kurucu şekli emredici hükümlere aykırılık durumunda ortaya çıacağ savunulmaktadır ${ }^{25}$. Yokluğun bir hukuki işlemin kurucu unsurundaki eksikliği ifade etmesinden hareket edildiğinde, kurucu unsurun belirlenmesi önem arz eder. Bu sebeple çok taraflı bir hukuki işlem olan limited şirket genel kurul kararlarının kurucu unsurunun ne veya neler olduğu belirlenmelidir. Bir genel kurul kararının varlığından bahsedilebilmesi için iki temel unsur bir arada bulunmalıdır. Bu unsurlar, genel kurul ve karardır ${ }^{26}$. Dolayısıyla bir genel kurul, kanunun öngördüğü şekli emredici hükümlere aykırı bir şekilde toplanmış veya karar almışsa, alınan bu karar yoklukla malûldür²7.

Doktrinde bir görüş, yok hükmünde olan genel kurul kararının şeklen meydana geldiğini fakat doğmamış sayıldığını ifade etmektedir ${ }^{28}$. Bir başka görüş ise yokluk yaptırımının kararın içeriğiyle değil meydana gelişiyle alakalı olduğunu ve bu sebeple kararın şeklen dahi meydana gelmediğini savunmaktadır 29 . Yargitay Hukuk Genel Kurulu da bir kararında, "kavram olarak yokluk; bir hukuki işlemin doğabilmesi için öngörülen ve kurucu nitelikte olan emredici hükümlere aykırılık hâlidir. Bu aykırılık, işlemin unsurlarında eksikliğe yol açar ve işlemi "yokluk" ile sakat hâle getirir. Yok sayılan işlem, şeklen dahi meydana gelmemiştir. Yokluk, bunu ileri sürme konusunda hukuki menfaati bulunan herkes tarafindan her zaman ileri sürülebilir ve tespit ettirilebilir, hâkim tarafından da re'sen dikkate alınır. Mahkemenin vereceği tespit hükmü, bu durumu açıklayıcı niteliktedir" diyerek

geçmektedir. Görüldüğü üzere kanun koyucu bu düzenlemede açıkça yokluk yaptırımından bahsetmektedir.

24 Önder, s. 111.

25 Kırca (Şehirali Çelik/Manavgat), s. 6; Moroğlu, s. 33; Bahtiyar, s. 198; Şener, Oruç Hami (2019) Ortaklıklar Hukuku Ders Kitabı, 4. Baskı, Ankara, Seçkin, s. 505; Bilgili, Fatih/Demirkapı, Ertan (2013) Şirketler Hukuku, 9. Baskı, Bursa, Dora, s. 342.

26 Moroğlu, s. 77 vd.; Önder, s. 107.

27 Poroy/Tekinalp/Camoğlu, s. 527.

28 Önder, s. 107.

29 Kırca (Şehirali Çelik/Manavgat), s. 4 
bu görüşü kabul etmiştir ${ }^{30}$. Mezkûr görüş bu durumdan hareket ederek, genel kurul kararlarının yokluğunun ancak genel kurulun meydana gelişini düzenleyen hükümlere aykırılık sonucu ortaya çıkabileceği sonucuna ulaşmaktadır $^{31}$. Kanaatimizce burada ikinci görüşe itibar edilmelidir. Başka bir deyişle yoklukla malûl olan genel kurul kararı şeklen dahi meydana gelmemiştir. Zira “yok” olan bir şeyin şekli anlamda varlığından bahsetmek mantıken ve hukuken mümkün değildir.

İsviçre hukukunda, yokluk ve butlan arasında bir ayrım yapmak yerine her iki kavramı da kapsayacak şekilde "Nichtigkeit" kavramının kullanıldığı görülmektedirr ${ }^{32}$. İsviçre hukukunda yok hükmündeki genel kurul kararları için "Schein Beschlüsse" 33 veya "Nicht Beschlüsse" 34 kavramları kullanılmaktadır ${ }^{35}$. Yani İsviçre hukukunda butlan ile yokluk arasında bir fark olduğu kabul edilmekle beraber ayrı bir yaptırım mekanizması öngörülmemiştir ${ }^{36}$. Dolayısıyla söz konusu hukuk sistemi bakımından Türk

30 Yargitay Hukuk Genel Kurulu, E: 2013/11-1048, K: 2014/430, T: 02.04.2014.

(https://karararama.yargitay.gov.tr/YargitayBilgiBankasiIstemciWeb/) s.e.t.: 24.03.2020.

31 Kırca (Şehirali Çelik/ Manavgat), s. 4. Sözleşmeler hukukunda şekle aykırılığın yaptırımı tartışmalıdır. Doktrinde butlan, yokluk ve kendine özgü geçersizliğe tabi olduğu yönünde görüşler vardır. Tartışma konusunda bkz. Kocayusupaşaoğlu (Hatemi / Serozan/ Arpacı), $\$ 29$, N. 2 vd. Doktrinde Nomer ise yokluk hâllerinin sadece usule ilişkin sebeplerden değil aynı zamanda içeriğe ilişkin nedenlerden de kaynaklanabileceğini savunmaktadır (Nomer, Haluk Nami (2008) Kişi Birliklerinde Genel Kurul Kararlarının Geçersizliğine İlişsin Temel Esaslar, İstanbul, Seçkin, s. 68 vd.)

Örneğin İsBorK m. 706/1/a. Ayrıca bkz. Truffer, Roland/Dubs, Dieter (2012) Artikel Kommentar zu OR Art. 698-706b,[içinde: Basler Kommentar Obligationenrecht II, Honsell, Heinrich / Vogt, Nedim Peter / Watter, Rolf], Basel, Helbing\&Lichtenhahn, Art. 706b, N. 17-18.

Sözde/Görünürde Karar.

34 Olmayan Karar.

Truffer/Dubs, Art. 706b, N. 17 vd.

Truffer/Dubs, Art. 706b, N. 17-18; Herkes tarafından ileri sürülebileceği yönünde bkz. Böckli, Peter (2009) Schweizer Aktienrecht mit Fusionsgesetz, Börsengesellschaftsrecht, Konzernrecht, Corporate Governance, Recht der Revisionsstelle und der Abschlussprüfung in neuer Fassung - unter Berücksichtigung der angelaufenen Revision des Aktien- und Rechnungslegungsrechts, 4. Auflage, Zürich, Schulthess, \$16, N. 156; 
hukukundaki gibi sonuçları itibariyle butlandan ayrılan bir yokluk kavramından bahsetmek mümkün değildir. Ancak İsviçre hukukunda şekle ilişkin ağır eksikliklerden kaynaklanan butlan hâllerinin, genel itibariyle Türk hukuku bağlamında yokluk yaptırımına benzer olduğu söylenebilir ${ }^{37}$.

Yokluk, özü itibariyle şeklen dahi var olmayan genel kurul kararlarına ilişkin bir yaptırımdır. Bundan dolayı bu yaptırıma sebebiyet verecek eksiklikler de genellikle genel kurula ilişkin usulî noktalarda tezahür eder. O hâlde örnek mukabilinde bir sayma yapılırsa ${ }^{38}$; çağrı yapılmadan toplanan genel kurullarda alınan kararlar ${ }^{39}$, çağrı yapılmamasına eş bir durumda toplanan genel kurullarda alınan kararlar $^{40}$, toplantı ve karar nisaplarına riayet edilmeksizin alınan kararlar ${ }^{41}$, Ticaret Bakanlığı temsilcisinin bulunması gerektiği hâllerde, temsilci olmaksızın gerçekleştirilen toplantılarda alınan kararlar $^{42}$, hakkında hiç oylama yapılmadığı hâlde, yapılmış gibi gösterilen kararlar ve yetkisiz kişiler tarafından yapılan çağrı ile toplanan genel kurulda alınan kararlar ${ }^{43}$ yoklukla malûldürler.

Schott, Bertrand (2009) Aktienrechtliche Anfechtbarkeit und Nichtigkeit von Generalversa mmlungsbeschlüssen wegen Verfahrensmängeln, Zürich/St. Gallen, Dike, \$7, N. 3.

Bu sebeple yokluğa ilişkin konularda İsviçre kaynaklarına yapılan atıflar, bu kaynaklarda butlan başlığı altında yer almaktadır. Kırca da eserinde bu hususu ifade etmektedir. (Kırca (Şehirali Çelik / Manavgat), s. 6 vd.).

Domaniç, Hayri/Arslanlı, Halil (1989) Türk Ticaret Kanunu Şerhi C. III, İstanbul, s. 633; Moroğlu, s. 100; Deryal, Yahya (2000) Ticaret Hukuku, 4. Bas1, Trabzon, Derya, s. 400; Önder, s. 111. Çağrısız genel kurula ilişkin Türk Ticaret Kanunu'nun 416'ncı maddesi bu durumun istisnasıdır. Mezkûr hükme aykırı olarak toplanan anonim ve limited şirket genel kurulunda alınan kararlar da yoklukla malûldür. Bkz. Yargitay 11. Hukuk Dairesi, E: 2000/10968 K: 2001/1616, T: 26.02.2001 (Önder, s. 121-122); Yargitay 11. Hukuk Dairesi, E: 2018/3976, T. 2018/3976 K: 2019/5402, T: 16.09.2019.

(https://karararama.yargitay.gov.tr/YargitayBilgiBankasiIstemciWeb/) s.e.t.: 24.03.2020.

Örneğin genel kurul toplantısından bir gün önce çağrının yapılması.

41 Çamoğlu, (Poroy/ Tekinalp), N. 722a; Önder, s. 111.

42 Korkut, Ömer (2012) 6102 Sayılı Türk Ticaret Kanunu'na göre Anonim Şirketlerde Genel Kurul Kararlarının Butlanı, Adana, Karahan, s. 37.

43 Yargitay 11. Hukuk Dairesi, E: 2018/112, K: 2019/6571, T: 22.10.2019.

(https://karararama.yargitay.gov.tr/YargitayBilgiBankasiIstemciWeb/) s.e.t.: 24.03.2020 . 


\section{B. BUTLAN}

Türk Borçlar Kanunu'nun ${ }^{44}$ 27. maddesine göre, emredici hükümlere, ahlâka, kamu düzenine, kişilik haklarına aykırı veya konusu imkânsız olan sözleşmeler kesin olarak hükümsüzdür ${ }^{45}$. Bir hukuki işlemin, kurucu unsurlarının tamam olmasına rağmen, geçerlilik şartlarının mevcut olmaması hâlinde o hukuki işlem batıl olacaktır ${ }^{46}$. Batıl olan hukuki işlem ölü doğmuştur ${ }^{47}$. Dolayısıyla, böyle bir hukukî işlem kural olarak başından itibaren geçersizdir; hüküm ve sonuçlarını doğurmaz ${ }^{48}$.

$\mathrm{Bu}$ açıdan bakıldığında yokluğun ve butlanın sonuçlarının aynı ve fakat sebeplerinin farklı olduğu söylenebilir. Zira her ikisinde de hukuki işlem baştan itibaren geçersiz olduğu için beklenen hüküm ve sonuç doğmaz. Fakat bir hukuki işlemin yoklukla malûl olabilmesi için kurucu unsurlarının eksik olması gerekirken; batıl olabilmesi için kurucu unsurları tamam ama geçerlilik şartları eksik olmalıdır.

Butlan tıpkı yokluk gibi, süresiz olarak bütün menfaat sahipleri tarafından ileri sürülebildiği gibi, mahkeme tarafından re’sen göz önüne alınmaktadır $^{49}$. Butlan yaptırımın sınırını Türk Medeni Kanunu'nun 2. maddesinde düzenlenen hakkın kötüye kullanılması yasağı oluşturmaktadır ${ }^{50}$.

Butlanın Türk şirketler hukukundaki tarihi gelişimine bakıldığında, herhangi bir pozitif düzenleme bulunmaksızın doktrin ve yargı kararlarıla gelişen bir süreç izlediği görülmektedir. Gerçekten de 6762 sayılı Türk Ticaret

\footnotetext{
44 R.G. T. 4/2/2011 S.27836.

TBK'da butlan yerine kesin hükümsüzlük terimi kullanılmıştır. (e)BK m. 20'de ise butlan terimi tercih edilmişti.

Oğuzman/Öz, s. 174.

Reisoğlu, Safa (2004) Borçlar Hukuku Genel Hükümler, 16. Bası, İstanbul, Beta, s. 121; Akıntürk, Turgut (2001) Borçlar Hukuku Genel Hükümler, 8. Bası, İstanbul, Beta, s. 56; Kılıçoğlu, Ahmet (2003) Borçlar Hukuku, 3. Bası, Ankara, s. 50. Kocayusupaşaoğlu (Hatemi / Serozan/ Arpacı), N. 10; Antalya, s. 129.

Edis, s. 148; von Tuhr, Andreas (1983) Borçlar Hukuku C. 1-2, , Ankara, Yargitay, (Çeviren: Edege, Cevat), s. 222; Antalya, s. 131; Oğuzman/Öz, s. 175; Kocayusupaşaoğlu (Hatemi / Serozan/ Arpacı), \$43, N. 20-21; Pulaşlı, Hasan (2013) “Anonim Şirket Genel Kurul Kararlarının Sakatlı̆̆ı ve Müeyyidesi”, GÜHFD, C. XVII, S. 1-2, s. 891. 
Kanunu döneminde anonim ve limited şirket genel kurul kararlarının butlanına ilişkin özel bir hüküm mevcut değildi. Ancak genel hüküm olarak butlanı düzenleyen 818 sayılı (mülga) Borçlar Kanunu'nun 20. maddesi, hem Türk Medeni Kanunu'nun 5. maddesindeki genel atıf hükmü ${ }^{51}$, hem de Türk Ticaret Kanunu'nun $1^{\prime}$ inci $^{52}$ maddesi gereği, anonim ve limited şirket genel kurul kararlarının butlanı açısından da uygulama alanı bulmuştur. Dolayısıyla bir genel kurul kararı şeklen geçerli olsa bile konusu itibariyle Borçlar Kanunu'nun 19 ve 20 'nci maddelerine aykırı ise batıldır. Böyle bir kararın ise sonuçlarını meydana getirmesi mümkün değildir ${ }^{53}$.

Mülga Türk Ticaret Kanunu ve Borçlar Kanunu döneminde doktrinde şirketler hukukuna özgü butlan sebeplerinin belirlenmesi gerektiği fikri serdedilmiştir $^{54}$. Nihayet 6102 sayılı Türk Ticaret Kanunu'nun 447’nci maddesi ile anonim şirket genel kurul kararlarının butlanına ilişkin pozitif bir düzenleme ihdas edilmiştir ${ }^{55}$. Söz konusu hüküm ile uzun yıllara dayanan anonim şirket genel kurul kararlarının butlanına ilişkin uygulama hükme bağlanmış ve butlan sebepleri somut bir şekilde gösterilmiştirr ${ }^{56}$. Mezkûr düzenleme Türk Ticaret Kanunu'nun 622'nci maddesi gereği limited şirket genel kurul kararları için de uygulanma kabiliyetini haizdir.

İsviçre hukukunda ise, anonim şirket genel kurul kararlarının butlanı, 1991 yılında geçekleştirilen revizyon ile İsviçre Borçlar Kanunu'nun 706b

51 TMK m. 5: "Bu Kanun ve Borçlar Kanununun genel nitelikli hükümleri, uygun düştüğü ölçüde tüm özel hukuk ilişkilerine uygulanır”.

52 TTK m. 1/1: "Türk Ticaret Kanunu, 22/11/2001 tarihli ve 4721 sayılı Türk Meden̂े Kanununun ayrılmaz bir parçasıdır”. Benzer hüküm 6762 sayılı ETTK m.1/1'de de yer almaktayd. Buna göre "Türk Ticaret Kanunu, Türk Medeni Kanununun ayrılmaz bir cüzüdür”.

53 Mülga Türk Ticaret Kanunu döneminde doktrinde "sadece belli bir yönde sonuç doğurması taahhüdünü içeren oy anlaşmasıyla oluşturulmuş bir genel kurul kararının ahlaka aykırılık teşkil edeceği ve bu sebeple BK. m. 20 gereği batıl olacağı” görüşü dermeyan edilmiştir (Önder, s. 108).

54 Tekinalp, Ünal, "Genel Kurul Kararlarının Butlanında Anonim Ortakliğa Özgü Sebeplerin Kabulü İhtiyacı", BATIDER, C. XXV, S. 4, s. 5 vd.

55 Anonim şirket genel kurul kararlarının butlanına ilişkin ayrıntılı bilgi için bkz. Korkut, s. $51 \mathrm{vd}$.

56 Bkz. TTK m. 447’nin gerekçesi. 
maddesinde düzenlenmiştir. Söz konusu hüküm Türk Ticaret Kanunu 447’nci maddesinin mehazıdır ${ }^{57}$.

Türk Ticaret Kanunu'nun 447'nci maddesine göre, “genel kurulun, özellikle pay sahibinin, genel kurula katılma, asgari oy, dava ve kanundan kaynaklanan vazgeçilemez nitelikteki haklarını sınılandıran veya ortadan kaldıran; pay sahibinin bilgi alma, inceleme ve denetleme hakların kanunen izin verilen ölçü dışında sınırlandıran ve anonim şirketin temel yapısını bozan veya sermayenin korunması hükümlerine aykırı olan, kararları batıldır." İsviçre Borçlar Kanunu'nun 706b maddesinde de hemen hemen aynı hâllerin, ifade farklılıkları ile butlan sebepleri olarak sayıldığı görülmektedir.

Madde lafzında geçen “özellikle” ifadesinden de anlaşıldığı üzere hem Türk Ticaret Kanunu'nun 447’nci hem de İsviçre Borçlar Kanunu’nun 706b maddesinde sayılan genel kurul kararlarının butlan sebepleri tahdidi değildir. Her iki kanunun da lafzı bu yönde açıktır ${ }^{58}$. Bu bağlamda doktrinde genel itibariyle kabul edildiği üzere Türk Ticaret Kanunu'nun 447’nci maddesi, Türk Borçlar Kanunu'nun 27'nci maddesinde yer alan butlan düzenlemesini dışlamamaktadır. Bir başka ifadeyle, Türk Borçlar Kanunu'nun 27’nci maddesine dayanılarak, genel kurul kararlarının butlanının ileri sürülebilmesi de mümkündür ${ }^{59}$. Dolayısıyla mülga Türk Ticaret Kanunu dönemindeki genel kurul kararlarının butlanına ilişkin uygulamadan tam olarak vazgeçildiğini söylemek mümkün değildir. 6102 sayılı Türk Ticaret Kanunu ile sadece anonim ve limited şirket genel kurul kararlarını batıl hale getiren birtakım sebepler tadâdi bir şekilde düzenlenmiştir.

\section{C. İPTAL EDİLEBİLİRLIIK}

Yoklukla malûl veya batıl olan bir hukuki işlem baştan itibaren hüküm ve sonuç doğurmaz. Bunlar dışında kalan diğer sakatlık halleri iptal edilebilirliktir. Bu sakatlık halinde karar hukuken geçerlidir, fakat kararın

57 Bkz. TTK m. 447'nin gerekçesi.

58

Her iki maddenin de lafzında, butlanla sakat genel kurul kararları sayılırken "özellikle (insbesondere)" ifadesine yer verildiği görülmektedir.

59

Kırca (Şehirali Çelik/Manavgat), s. 18 vd.; Korkut, s. 99 vd.; Moroğlu, s. 158 vd. 
bünyesinde yer alan bir nedenden dolayı iptali talep edilebilir. İptali talep edecek kişiler kanunun öngördüğü süre içerisinde bunu talep etmelilerdir. Aksi halde söz konusu karar bünyesinde barındırdığı eksikliğe rağmen geçerliliğini muhafaza edecektir.

\section{D. ŞİRKETLER HUKUKU AÇISINDAN YOKLUK ile BUTLAN ARASINDAKİ TEMEL FARKLAR}

İsviçre hukukuna nazaran, Türk hukukunda yokluk ile butlan arasında daha net bir ayrım vardır. Yukarıda da bahsedildiği üzere İsviçre hukukunda, yokluk ile butlan arasında bir farklılı̆gın mevcut olduğu kabul edilmekle beraber, sonuçları itibariyle bir ayrım yapılmamaktadır. Her ne kadar her iki sakatlık halinde de hukuki işlem başından itibaren geçersiz olsa da Türk hukukunda bu iki hükümsüzlük hali bakımından birkaç önemli farklılığın var olduğu kabul edilmektedir. Bunlardan ilki tahvil müessesesi ile ilgilidir. Butlanın aksine yoklukta tahvil yoluna gidilmesinin mümkün olmadığı kabul edilmektedir $^{60}$. Ayrıca daha önce de vurguladığımız üzere yokluk ile butlan arasında sebepleri yönünden de farklılık mevcuttur. Bir genel kurul kararının yok hükmünde olabilmesi için kanunun öngördüğü kurucu unsurların eksik olması gerekirken, batıl olabilmesi için ise ya Türk Ticaret Kanunu'nun 447’nci ya da Türk Borçlar Kanunu'nun 27'nci maddesindeki sebeplerin gerçekleşmesi gerekir.

Zikrolunan bu farklılıkların yanında söz konusu iki hükümsüzlük hali arasındaki temel fark, hakkın kötüye kullanılması yasağı bağlamında ortaya çıkar. Butlanın aksine yokluğun tespitinin dava edilmesi halinde karşı tarafın yani davalının, davacının hakkın kötüye kullanılması yasağını ihlal ettiğini ileri sürmesinin mümkün olmadığı kabul edilir ${ }^{61}$. Bittabi bu husus şirket genel

\footnotetext{
60 Kocayusupaşaoğlu (Hatemi / Serozan/ Arpacı), \$43, N. 2; Kırca (Şehirali Çelik / Manavgat), s. 2.

61 Oğuzman/Barlas, s. 212; Kocayusupaşaoğlu (Hatemi/Serozan/Arpacı), \$43, N. 2; Kırca (Şehirali Çelik/Manavgat), s. 2; Moroğlu, s. 37; Korkut, s. 40; Yüce, Onur Alber (2015) Anonim Şirketlerde Yönetim Kurulu Kararlarının Butlanı, 2. Baskı, İstanbul, Vedat, s. 68; Nomer, s. 62: Üçışık, Güzin/Çelik, Aydın (2013) Anonim Ortaklıklar Hukuku, C. 1, Ankara, Adalet, s. 341; Aytaç, Zühtü (1982) Anonim Ortaklıklarda İbra, Ankara, Banka ve
} 
kurul kararlarının yokluğunun tespitinin dava edilmesi halinde de söz konusu olmalıdır. Dolayısıyla kanaatimizce bir anonim veya limited şirket genel kurul kararının yokluğunun tespitinin dava edildiği hallerde davalı, hakkın kötüye kullanılması yasağının ihlal edildiğini ileri sürememelidir.

\section{GENEL KURUL KARARLARININ HÜKÜMSÜZLÜĞÜ HALİNDE AÇILABİLECEK DAVALAR}

\section{A. İPTAL DAVASI}

Şirket genel kurul kararlarının hükümsüzlük hallerinden biri iptal edilebilirliktir. İptal edilebilir bir genel kurul kararının iptalinin söz konusu olabilmesi için dava açılması gerekir. Hem 6762 sayılı hem de 6102 sayılı Türk Ticaret Kanunu'nda limited şirket genel kurul kararlarının iptali anonim şirket genel kurul kararlarının iptaline ilişkin hükümlere tâbi tutulmuştur. Zira kanun koyucu 6762 saylı kanunun 536'nc1 maddesinin dördüncü fikrasında ve 6102 sayılı kanunun 622'nci maddesinde anonim şirket genel kurul kararlarının iptaline ilişkin hükümlerin limited şirket için de uygulanma kabiliyetini haiz olduğunu açıkça belirtmiştir.

Hem 6762 sayılı kanunun 381'inci hem de 6102 sayll kanunun 445'inci maddelerinde genel kurul kararlarının iptalini gerektirecek sebepler benzer şekilde düzenlenmiştir. Söz konusu hükümlere göre kanuna, esas sözleşmeye veya dürüstlük kurallarına aykırı genel kurul karalarını iptali talep edilebilir. İptal davası genel kurul karar tarihinden itibaren üç ay içerisinde şirket tüzel kişiliğine karşı açılır. Üç aylık dava açma süresi hak düşürücü süredir ${ }^{62}$.

Mahkemenin iptal davasını kabul etmesi başka bir deyişle dava konusu genel kurul kararını iptal etmesi, o kararın kanuna, esas sözleşmeye veya

Ticaret Hukuku Araştırma Enstitüsü, s. 186-187; Pulaşlı, Hasan (2017) Şirketler Hukukunun Esasları, 5. Baskı, Ankara, Adalet, s. 390; Zeytin, Zafer/Ergün, Ömer (2017) Türk Medeni Hukuku, 3. Baskı, Ankara, Seçkin, s. 58; Hatemi, Hüseyin (2011) Medeni Hukuk'a Giriş, 5. Baskı, İstanbul, Vedat, s. 159-160; Antalya, Gökhan/Topuz, Murat (2015) Medeni Hukuk, İstanbul, Legal, s. 223; Turanlı, Hüsnü (2013) "Yeni Türk Ticaret Kanunu Işığında Anonim Şirket Yönetim Kurulu Kararlarının Hükümsüzlüğü”, GÜHFD, C. XVII, S. 1-2, s. 948. Karşı görüş için bkz. Poroy/Tekinalp/Çamoğlu, s. 530, N. 722 f. 
dürüstlük kurallarına aykırı olduğunun tespiti anlamına gelir. Böyle bir durumda bu kararın geçerliliği ortadan kalkar ${ }^{63}$.

\section{B. TESPIT DAVASI}

Tespit davası konusu itibariyle yok veya batıl olan genel kurul kararları ile ilişkilidir. Burada mahkemenin kararı, olan bir durumu sadece açıklamaktan ibarettir ${ }^{64}$. Zira yok hükmünde olan bir karar şeklen dahi varlık kazanamamıştır. Başka bir deyişle hiç doğmamıştır. Batıl olan kararlar ise ölü doğmuştur. Bu sebeple her iki durumda da kararlar baştan itibaren hüküm ve sonuç doğurmaz. Bundan dolayı da hukuki yararı bulunan herkes herhangi bir süre bağlı olmaksızın genel kurul kararın yok hükmünde veya batıl olduğunun tespitini mahkemeden talep edebilir ${ }^{65}$. Bu dava şirket tüzel kişiliğine karşı açılmalıdır.

Genel kurul kararının yok hükmünde veya batıl olduğunun tespitine ilişkin davanın herhangi bir süreye bağlı olmaması ister istemez şirketi sürekli dava tehdidi altında tutmaktadır. Bunun ise şirket açısından özellikle iktisadi anlamda ağır sonuçlar doğurabileceği aşikârdır ${ }^{66}$. Fakat bunun genel kuralı değiştirmemesi gerekir.

Burada sadece butlan açısından bir istisna getirilebilir ${ }^{67}$. Daha önce de belirtildiği üzere butlan durumunda şekli anlamda bir genel kurul kararı mevcuttur. Bu kararı ve butlan sebeplerini bilen bir kişi uzun bir süre

63 Önder, s. 115.

64 Tanrıver, Süha (2018) Medeni Usul Hukuku Temel Kavramlar ve İlk Derece Yargılaması, C. I, Ankara, Yetkin, s. 584, 585; Pekcanıtez, Hakan (2017), Pekcanitez Usul Medeni Usul Hukuku, 15. Bası, İstanbul, Onikilevha, s. 972.

65 Önder, s. 111. Bkz. Yargitay Hukuk Genel Kurulu E: 2018/11-246, K: 2008/239, T: 12.03.2008; Yargitay 11. Hukuk Dairesi, E: 2018/835, K: 2019/5869, T: 26.09.2019

(https://karararama.yargitay.gov.tr/YargitayBilgiBankasiIstemciWeb/) s.e.t.: 24.03.2020.

Doktrinde Kendigelen, kanun koyucunun butlana ilişkin düzenlemede, Alman Paylı Ortaklıklar Kanunu m. 242/2'nin aksine, bir süre sınırı öngörmemiş olmasının bir eksiklik olduğunu dile getirmektedir. (Kendigelen, Abuzer (2016) Türk Ticaret Kanunu Değişiklikler, Yenilikler, İlk Tespitler, 3.baskı, İstanbul, Onikilevha, s. 34).

67 Butlan halinde dahi süre sınırının uygulanamayacağı yönünde görüş için bkz. Önder, s. 112 . 
geçmesine rağmen tespit davası açmamışsa artık diğer kişilerde söz konusu davanın açılmayacağı yönünde bir inanç oluşabilir. Kanaatimizce böyle bir inancı oluşturduktan sonra ilgili kişinin tespit davası açması çelişkili davranış yasağını ihlal ettiği anlamına gelir. Çelişkili davranış yasağının ihlali ise hakların dürüstlük kuralına uygun kullanılmasını öngören Türk Medeni Kanunu'nun 2'nci maddesi uyarınca hukuken korunmaz. Fakat bu istisnanın yokluğu da kapsayacak şekilde geniş uygulanmaması gerektiğini düşünmekteyiz. Yani uzun süre geçtikten sonra genel kurul kararının yokluğunun tespitinin dava edilmesi çelişkili davranış yasağının ve dolayısıyla hakkın kötüye kullanılması yasağının ihlali olarak değerlendirilmemelidir. Zira böyle bir durumda ortada vücut bulmuş herhangi bir karar yoktur. Var olmayan bir şey ise zamanla varlık kazanamaz.

\section{DEĞERLENDİRME}

C. O. A. S. Ltd. Şti. ortaklarından A. C.'nin, kendisinin katılmadığ genel kurullarda, sahte imzalarla katılmış gibi gösterilerek alınan sermaye artırımı kararları vasıtasıly, pay sahipliği oranı \%45’ten \%0,1'e düşürülmüştür. İlk derece yargılamasında alınan bilirkişi raporuyla, imzaların A. C.'ye ait olmadığı tespit edilmiştir. Dolayısıyla bu maddi vakıada üç temel tartışma söz konusudur. Bunlar; nisaba aykırı alınan genel kurul kararının yoklukla mı yoksa butlanla mı malûl olduğu, yoklukla malûl karar kapsamında hakkın kötüye kullanılması kurumunun uygulama alanı bulup bulmayacağı ve son olarak uygulanacağının kabulü halinde somut olayda hakkın kötüye kullanılmasının söz konusu olup olmadığıdır.

6762 sayılı Türk Ticaret Kanunu'nun 513'üncü maddesine göre, esas sözleşmede daha ağır bir nisap öngörülmemiş olması halinde limited şirkette sermaye artırım kararı sermayenin üçte ikisini oluşturan ortakların oyuyla alınabilir. 6102 sayılı Türk Ticaret Kanunu'nun 621'inci maddesinin birinci fıkrasının d bendine göre ise limited şirkette sermaye artırımına ilişkin genel kurul kararları, temsil edilen oyların en az üçte ikisinin ve oy hakkı bulunan esas sermayenin tamamının salt çoğunluğunun bir arada bulunması hâlinde alınabilir. 
İnceleme konusu Yargitay kararından da açıkça anlaşıldığı üzere bahsi geçen limited şirkette sermaye artırım kararları çağrısız genel kurullarda ortaklardan A. C.'nin katılımı ve olumlu oyu olmaksızın, bir başka ifade ile 6762 sayılı Türk Ticaret Kanunu'nda ${ }^{68}$ öngörülen toplantı ve karar nisaplarına uyulmaksızın alınmıştır. Türk Ticaret Kanunu'nun aradığı toplantı ve karar nisaplarına ve çağrısız genel kurulun şartlarına aykırı olarak alınan genel kurul kararları yok hükmündedir ${ }^{69}$. Yani bu kararlar şeklen dahi meydana gelmemiştir. Keza Yargıtay'ın içtihatlarının da bu yönde olduğu görülmektedir ${ }^{70}$.

Yargitay 11. Hukuk Dairesi'nin, kararında butlandan bahsetmesi kanaatimizce yerinde değildir. Zira yukarıda da belirttiğimiz üzere somut vakıada sermaye artırımı kararları çağrısız genel kurullarda kanunun aradığı nisaba aykırı alınmış olduğu için bu kararlar yoklukla malûldür. Butlan ve yokluk birbirinden farklı müesseselerdir. Kanunun aradığı nisaba aykırı karar alınması halinde butlanın tartışılması doğru değildir. Zira bu halde şirketin iradesi oluşmamıştır. Ortada kararının butlanı ileri sürülebilecek bir genel kurul dahi yoktur. Fakat 11. Hukuk Dairesi kararında ilk derece mahkemesinin yokluk kararını, butlan gibi kabul etmekte ve buna göre bir değerlendirmede bulunmaktadır. Hâlbuki ilk derece mahkemesi, kanaatimizce isabetli bir şekilde dava konusu genel kurul kararlarının butlanla değil yoklukla malûl olduklarını tespit etmiştir. 11. Hukuk Dairesi dava konusu genel kurul kararlarının yoklukla değil butlanla malûl oldukları kanaatinde ise, ilk derece mahkemesinin kararını öncelikle bu yönden değerlendirmesi

68 Daha önce de belirttiğimiz üzere söz konusu limited şirketteki sermaye artırım kararları 6762 sayılı Türk Ticaret Kanunu döneminde alınmıştır.

69 Kırca (Şehirali Çelik/Manavgat), s. 10; Çamoğlu (Poroy/Tekinalp), N. 722a; Pulaşlı (2017) s. 388; Üçışı/kÇelik, s. 337; Korkut, s. 37.

70 Yargitay 11. Hukuk Dairesi, E: 1992/5419, K: 1993/5826, T: 24.09.1993; 01.10.2001 T 2001/7442 E., 2001/7269 K.; Yargitay Hukuk Genel Kurulu, E: 2008/11-246, K: 2008/239, T: 12.03.2008; Yargitay 11. Hukuk Dairesi, E: 2016/2516, K: 2017/4670, T: 25.09.2017; E: 2016/3992, K: 2017/6210, T: 15.11.2017; E:2016/6071, K: 2018/221, T:11.01.2018; E: 2016/13422, K: 2018/4608, T: 20.06.2018; ../01/2019 T. 2017/2895 E. 2019/520 K.; E: 2017/2399, K: 2019/1822, T: 05.03.2019; E: 2018/788, K: 2019/5386, T: 16.09.2019; E: 2018/3976, K: 2019/5402, T: $16.09 .2019 \quad$ (https://karararama.yargitay.gov.tr/ YargitayBilgiBankasiIstemciWeb/) s.e.t.: 24.03.2020. 
gerekirdi. Bu sebeplerle Yargitay'nn aslında yok hükmünde olan genel kurul kararlarını batıl olarak kabul edip ona göre değerlendirme yapması kanaatimizce yerinde değildir ${ }^{71}$.

Davaya konu genel kurul kararlarının yok hükmünde olduğunun tespitinden sonra tartışılması gereken asıl mesele, hakkın kötüye kullanılması yasağının burada yoklukla malûl genel kurul kararlarının tespitinin talep edilmesi açısından uygulanıp uygulanmayacağıdır. Hukukumuzda hakkın kötüye kullanılması yasağının kaynağı Türk Medeni Kanunu'nun 2'nci maddesidir. Söz konusu hükmün birinci fikrasına göre "herkes, hakların kullanırken ve borçlarını yerine getirirken dürüstlük kurallarına uymak zorundadır”. Bu kuralın amacı, kişilerin, haklarını kullanırken veya borçlarını ifa ederken orta zekâya sahip bir kişiden beklenen davranışları göstermelerini sağlamaktır ${ }^{72}$. Kanun koyucu mezkûr hükmün ikinci fikrasında bir hakkın açıkça kötüye kullanılmasının ise hukuk düzenince korunmayacağını düzenlemiştir. Eğer bir hak, sahibi tarafından amacı dışında kullanılmışsa, kötüye kullanılmış olur ${ }^{73}$. Bir hakkın amacı dışında kullanılmış olup olmadığı her somut olayın kendi koşulları içerisinde değerlendirilmelidir ${ }^{74}$. Kanun koyucu, hakkın kötüye kullanılması yasağının müeyyidesini hukuk düzeni korumaz şeklinde ifade etmiştir. Yani bir hakka dayanan talep veya savunma, hakkın kötüye kullanılması yasağının ihlali anlamına geliyorsa bu talep veya savunma hukuk düzenince kabul edilmez ${ }^{75}$. Fakat doktrinde de açıkça ifade edildiği üzere, bir kişinin dürüstlük kurallarına uyup uymadığı veya hakkın

71 Yargıtay’ın buna benzer tespitleri başka kararlarında da yaptığı görülmektedir. Bu kapsamda Yargıtay'ın aslında yok hükmünde olan genel kurul kararlarını batıl; batıl olan genel kurul karalarını ise yok hükmünde kabul ettiği başka kararları da mevcuttur. Örneğin, Yargitay 11. Hukuk Dairesi, E: 1995/4655 K: 1995/7789 T: 20.10.1995; E: 1997/6671, K: 1997/6256, T: 25.09.1997; E: 2001/7442, K: 2001/7269, T: 01.10.2001; E: 2001/8310, K: 2002/757, T: 04.02.2002 (Önder, s. 115 vd.).

72 Oğuzman/Barlas, s. 250; Uyar, Talih (2000) "Yargitay Kararlarında "Dürüstlük (Objektif İyiniyet)" Kuralı (MK.2/I) ve "Hakkın Kötüye Kullanılması Yasağı” (MK.2/II)”: Zafer Gören Ataysoy (Editör), Seyfullah Edis'e Armağan, İzmir, Dokuz Eylül Üniversitesi, s. 439465, s. 440.

Oğuzman/Barlas, s. 257. 
kötüye kullanılması yasağını ihlal etmiş olup olmadığı değerlendirmesi yapılırken aşırıya kaçılmamalı ve bu kuralın ikinci derecede uygulanması gereken bir kural olduğu unutulmamalıdır ${ }^{76}$. Zira bu kuralı çok sık uygulamak hukuk emniyetini ortadan kaldırır ${ }^{77}$.

$\mathrm{Bu}$ kapsamda şu hususun tekrar vurgulanmasının önem arz ettiğini düşünüyoruz; yoklukla malûl kararlar şeklen dahi yokturlar. Doktrinde ${ }^{78}$ de isabetli olarak ifade edildiği üzere, şeklen dahi var olmayan yoklukla malûl kararların tespitinin talep edildiği hallerde, hakkın kötüye kullanıldığı savunmasının yapılması mümkün değildir. Yargıtay’n da bu görüşü tasdik eden birçok kararı vardır ${ }^{79}$. Bu durum yokluk ile butlan arasındaki en temel farklardan biridir. Dolayısıyla somut vakıada Yargitay'ın genel kurul kararlarının yoklukla malûl olduklarının tespitinin talep edilmesinde hakkın kötüye kullanılıp kullanılmadığının değerlendirilmesi gerektiğini ifade etmesi yerinde değildir.

Bir an için yokluğun tespiti davasında hakkın kötüye kullanılması yasağının tartışılmasının mümkün olduğu kabul edilse dahi, somut davada uygulanması yine de mümkün değildir. Şöyle ki, yukarıda yapılan ayrıntılı açıklamalardan anlaşılacağı üzere dava konusu genel kurul kararlarının altına davacı A.C.'nin imzasını taklit ederek imza atan kişi diğer ortak G.C.'dir. G.C. bunu tek sefer değil, müteaddit kereler yapmıştır. G.C.'nin bu davranışında kasten ve hukuka aykırı hareket ettiği izahtan varestedir. Sahte imza ile işlem yapmayı ise hiçbir hukuk sistemi korumaz. G.C., A.C.'nin imzasını taklit ederek sadece sakat bir genel kurul kararının ortaya çımasına neden olmamış aynı zamanda bundan menfaat de temin etmiştir. Zira bu şekilde alınan

\footnotetext{
Uyar, s. 441, 443.

Oğuzman/Barlas, s. 302.

78 Bkz. dpn. 61'de sayılan müellifler.

79 “...işlemde "yokluk" söz konusu ise, işleme MK m. 2'ye dayanılarak sağlık kazandırılması asla mümkün değildir". Bkz. Yargitay 2. Hukuk Dairesi, T: 20.11.1970, S: 5584/6134 (İBD, 1971/11-12, s. 1046 vd.). Yargitay 2. Hukuk Dairesi, T: 20. 11.1970, S: 5577 /6142 (RKD. 1971, II/2, s. 17). "Yokluk durumunda, yokluğu ileri sürmenin dürüstlük kuralına ve hakkın kötüye kullanılması yasağına aykırılık teşkil ettiği gerekçesiyle dahi olsa işlemin ayakta tutulması (var ve geçerli sayılması) mümkün değildir”. Bkz. Yargitay 2. Hukuk Dairesi, T: 20. 11.1970, S: 5584/6134 (İBD, 1971/11-12, s. 1046 vd.).
} 
sermaye artırımlarına ilişkin kararlar neticesinde her defasında davacı A.C.'nin şirketteki \%45'lik pay oranı azalmış, nihayetinde \%0,1'e düşmüş ve bunun karşılığında G.C.'nin pay oranı önemli ölçüde artmıştır. Yani G.C. hukuka aykırı hareketi neticesinde hem genel kurul kararlarının yoklukla malûl olmasına sebebiyet vermiş hem de bu hukuka aykırılıktan menfaat temin etmiştir. Bundan dolayı söz konusu genel kurul kararlarının yokluğunun tespiti davasında hakkın kötüye kullanılması yasağının ihlâl edildiği savunmasına itibar edilmemesi gerekir. Çünkü kimse kendi kusurundan menfaat temin edemez. Aksini kabul etmek, hâkime özel ve istisnai durumlarda adil karar verme imkânı sağlamak amacıyla ${ }^{80}$ öngörülen hakkın kötüye kullanılması yasağını, haksızlı̆̆ın aracı haline getirmektedir. Kanaatimizce kanun koyucu hakkın kötüye kullanılması yasağını düzenlerken böyle bir sonucu istemiş değildir.

Yargıtay, davacının dava açmak hakkını kötüye kullanmasının esas gerekçesi olarak, dava konusu genel kurul kararlarının tarihi ile bu kararların yoklukla malûl olduğunun tespiti için dava açılması tarihleri arasındaki geçen sürenin uzunluğunu göstermiştir. Kanaatimizce Yargitay bu değerlendirmesi ile hak sahibinin, dava açma noktasında uzun süre sessiz kalmasının onun dava açma hakkından vazgeçtiği şeklinde yorumlanması gerektiği sonucuna varmıştır. Başka bir deyişle bir hakkın ihlâline uzun bir süre sessiz kalınması o ihlâle karşı dava açılmayacağı inancını oluşturur. Bu inanç oluştuktan sonra dava açılması ise çelişkili davranış yasağının ihlâli anlamına gelir. Uzun süre sessiz kalarak dava açmayacağı yönünde inanç oluşturan kişi, eğer dava açarsa çelişkili davranış yasağını ihlâl ettiği kabul edilir ve bu davranışı Türk Medeni Kanunu'nun 2'nci maddesi uyarınca hukuk düzeni tarafından korunmaz. Pek tabi ki tüm bu hususların takdiri mahkemeye aittir. Kanaatimizce mahkeme burada takdir yetkisini kullanırken keyfi bir tutum izlememeli ve olabildiğince bu yasağın uygulama alanını sınırlı tutmalıdır. Herhangi bir süre sınırına tabi olmaması sebebiyle, yokluğun ve butlanın tespiti davalarında asıl olan her zaman açılabilmeleridir. Bir başka ifade ile üzerinden süre geçmiş olması dava hakkını kendiliğinden sonlandırmamalıdır. Alman Paylı Ortaklıklar Kanunu'nun aksine Türk Ticaret Kanunu'nda butlanın tespiti davası için bir 
süre sınırı öngörülmemiş olması da bu görüşü kuvvetlendirmektedir. Hiç şüphesiz, batıl kararın alınmasının üzerinden uzun süre geçmesi, hakkın kötüye kullanılması yasağı kapsamına girebilecektir ${ }^{81}$. Ancak bu kapsama giriş, tek başına süre geçmesinden değil, süreye ek olarak başka şartların da bulunmasıyla gerçekleşecektir ${ }^{82}$. Aksi durumda haksızlığı önleme saikiyle ortaya çıkan bir müessese haksızlığın aracı haline gelir ${ }^{83}$.

Bir hakkın ihlâline uzun süre sessiz kalınarak o ihlâle karşı dava açılmayacağı inancını oluşturduktan sonra dava açılmasının çelişkili davranış yasağının ihlâli anlamına gelmesi aslında Türk hukukuna yabancı değildir. Bu ilkenin Yargıtay kararlarında uzunca bir süredir kullanıldığı görülmektedir. "Sessiz kalma nedeniyle hak kaybi" Yargitay kararlarında genellikle marka hukukuna ilişkin davalarda uygulanmaktadır. Şöyle ki, tescilli bir markanın sahibi, markasının üçüncü kişiler tarafından izni olmadan kullanıldığını bilmesine rağmen uzun süre sessiz kalıp dava açmayarak dava açmayacağ 1 yönünde güven oluşturduktan sonra marka hakkına tecavüz edildiği iddiasıyla dava açarsa, bu dava açma hakkının kötüye kullanıldığı anlamına geliir ${ }^{84}$.

Çalışmaya konu ettiğimiz karara bakıldığında, Yargıtay, uzun süre şirket genel kurul kararlarının yokluğunun tespitinin talep edilmemesinin artık buna ilişkin bir talep ileri sürülmeyeceğine yönelik bir inanç oluşturduğunu ve bu inanç oluştuktan sonra tespit davası açılmasının çelişkili

81 Aynı görüşün İsviçre’de de kabul gördüğü yönünde bkz. Moroğlu, s. 196-196.

82 Örneğin, butlanı ileri sürülen kararın kimseye zarar vermemiş olması veya en baştan beri bildiği uyuşmazlığa menfaati gereği ses çıarmayan kişinin, uzun süre geçtikten sonra dava açması gibi (Moroğlu, s. $195 \mathrm{vd}$.).

83 Akyol, Şener (2006) "Venire Contra Factum Proprium (Önceki Eylem ile Çelişkili Davranış Yasağı)”: Ünal, Mehmet (Editör), Fikret Eren’e Armağan, Ankara, Yetkin, s. 80,94.

846769 sayılı Sınai Mülkiyet Kanunu'nun 25'inci maddesinin altıncı fikrasında "sessiz kalma nedeniyle hak kaybı" hükümsüzlük davaları bakımından düzenlemiştir. Söz konusu hükme göre "Marka sahibi, sonraki tarihli bir markanın kullanıldı̆̆ını bildiği veya bilmesi gerektiği hâlde bu duruma birbirini izleyen beş yıl boyunca sessiz kalmışsa, sonraki tarihli marka tescili kötüniyetli olmadıkça, markasını hükümsüzlük gerekçesi olarak ileri süremez". Ayrıca bkz. Sınai Mülkiyet Kanunu'nun 25'inci maddesinin altıncı fikrasının gerekçesi (https://www.tbmm.gov.tr/sirasayi/donem26/yil01/ss341.pdf, (s.e.t.: 20.03.2020). 
davranış yasağının ihlâli anlamına geleceğini, dolayısıyla hakkın kötüye kullanılması sonucunu doğuracağını belirtmek istemiştir.

Kanaatimizce Yargıtay'ın bu değerlendirmesi hatalıdır. Şöyle ki, daha önce de belirtildiği üzere dava konusu genel kurul kararları kanunun öngördüğü nisaplara aykırı olarak alındıkları için yoklukla malûldürler. Başka bir deyişle bu kararlar hukuk âleminde şeklen dahi olsa meydana gelmemişlerdir. Yani bahis konusu olabilecek ortada herhangi bir genel kurul kararı mevcut değildir. Kanaatimizce bir genel kurul kararının yokluğunun tespiti davasında uzun süre dava açılmamasından sonra tespit davasının açılmasının hakkın kötüye kullanılması anlamına geldiği iddia etmek doğru değildir. Zira aksini düşünmek, yok hükmünde olan kararların sırf tespitleri dava edilmediği için zamanla sıhhat kazanmaları sonucunu doğurur. Başka bir deyişle, alındığ 1 anda aslında yoklukla malûl olan karar ilerleyen zamanlarda "var" olmuş yani geçerli hale gelmiş olur. Bunun ise hukuken mümkün olmadığını düşünmekteyiz. Keza yokluk zamanla varlık kazanamaz.

"Sessiz kalma nedeniyle hak kaybı" kurumunun yokluğun tespiti davasında uygulanabileceği kabul edilse dahi söz konusu Yargıtay kararına konu somut vakıada uygulanması yine de mümkün değildir. Zira yukarıda da belirttiğimiz üzere "sessiz kalma nedeniyle hak kaybı" ve buna paralel dava açma hakkının kötüye kullanılması mahkemelerce titiz uygulanmalı ve bir haksızlığın aracı haline gelmemelidir. Bu sebeple dava açma hakkının kötüye kullanıldığı yönünde savunma yapan kişilerin kendi davranışlarının dürüstlük kurallarına ve hukuka uygun olması gerekir. Marka hukukundaki uygulama da zaten bu şekildedir. Ki kanun koyucu bu hususu "sessiz kalma nedeniyle hak kaybı"nın somut olarak düzenlediği Sınai Mülkiyet Kanunu'nun 25’inci maddesinin altıncı fikrasında açıkça vurgulamıştır. Söz konusu hükme göre, marka sahibinin sessiz kalma nedeniyle hak kaybına uğraması için sonraki tarihli marka tescilinin kötüniyetli olmaması gerekir. Yani sonraki tarihli marka tescili kötüniyetli ise marka sahibi hükümsüzlük davası açması bakımından sessiz kalma nedeniyle hak kaybı yaşamaz. Somut vakıada sermaye artırımına ilişkin genel kurul kararlarının yoklukla malûl olmasına diğer ortak G.C. davacının imzasını taklit ederek sebebiyet vermiştir. Bu genel kurul kararları neticesinde G.C.'nin şirketteki pay oranı peyderpey artmıştır. 
Yani G.C. hem hukuka aykırı hareket etmiş hem de bundan bir menfaat temin etmiştir. Unutulmamalıdır ki, kimse kendi kusurundan menfaat temin edemez. Kendisinden beklenen hukuka ve dürüstlük kurallarına uygun davranma yükümlülüğünü ihlâl eden kişilerin karşı tarafın hakkını kötüye kullandığı yönünde bir savunma yapmaları, başlı başına hakkın kötüye kullanımıdır ve hukuk düzeni tarafından korunmamalıdır.

\section{SONUÇ}

Çalışmamıza ilişkin çıkardığımız sonuçlar şu şekildedir:

Anonim ve limited şirket genel kurul kararı kurucu şekli unsurları düzenleyen emredici hükümlere aykırı ise o karar yok hükmündedir. Yok hükmünde olan genel kurul kararları şeklen dahi meydana gelmemiştir.

Türk Ticaret Kanunu'nun toplantı ve karar nisaplarına veya çağrısız genel kurula ilişkin hükümlerine aykırı alınan genel kurul kararları yok hükmündedir.

Genel kurul kararının şekli kurucu unsurları mevcut ama geçerlilik şartları eksik ise o karar batıldır.

Bir genel kurul kararının yok hükmünde veya batıl olduğunun tespiti her zaman talep edilebilir. Söz konusu iki hükümsüzlük hali arasındaki temel fark, hakkın kötüye kullanılması yasağı bağlamında ortaya çıkar. Butlanın aksine yokluğun tespitinin dava edilmesi halinde karşı tarafın yani davalının, davacının hakkın kötüye kullanılması yasağını ihlal ettiğini ileri sürmesi mümkün değildir.

Çalışma konumuzu teşkil eden Yargıtay kararına konu somut olayda, çağrısız toplanan limited şirket genel kurul toplantılarına ortaklardan biri katılmamış, diğer ortak toplantı tutanağına katılmayan ortağın imzasını taklit ederek kararların alınmasını sağlamıştır. Yani bu kararlar Türk Ticaret Kanunu'nda öngörülen nisaplara ve çağrısız genel kurula ilişkin ilkelere uygun alınmamıştır. Dolayısıyla bu kararlar yok hükmündedir. Genel kurul toplantısına katılmayan ve imzası taklit edilen ortak, söz konusu kararların yokluğunun tespiti için dava açmış, ilk derece mahkemesi de dava konusu genel kurul kararlarının yok hükmünde olduğuna hükmetmiştir. 
Yargitay 11. Hukuk Dairesi ise genel kurul karar tarihlerinden uzun süre geçtikten sonra yokluğun ve butlanın tespiti davası açılmasının hakkın kötüye kullanılması yasağının ihlali anlamına geleceği gerekçesiyle ilk derece mahkemesi kararını bozmuştur. Söz konusu kararına bakıldığında Yargıtay’ın, hak sahibinin, dava açma noktasında uzun süre sessiz kalmasının onun dava açma hakkından vazgeçtiği şeklinde yorumlanması gerektiği sonucuna vardığı ve böyle bir sonuca varıldıktan sonra dava açılmasının ise Türk Medeni Kanunu'nun 2'nci maddesi bağlamında korunamayacağı kanaatinde olduğu görülmektedir.

Kanaatimizce Yargitay'ın "sessiz kalma nedeniyle hak kaybl" müessesesini yok hükmünde olan genel kurul kararları için uygulaması hatalıdır. Zira aksini düşünmek, "yok" hükmünde olan genel kurul kararlarının belli bir zaman geçtikten sonra "var" olması sonucunu doğurur. "Yok" olan bir şeyin zamanla "var" olması hukuken ve mantıken mümkün değildir.

Bununla birlikte hakkın kötüye kullanılması yasağı ilkesi mahkemelerce titiz uygulanmalı ve haksızlığın aracı haline gelmemelidir. Yani bu yasağın ihlali yönünde savunma yapan kişilerin kendi davranışlarının dürüstlük kurallarına ve hukuka uygun olması gerekir. Fakat Yargitay'ın mezkûr kararı vesilesi ile genel kurul kararlarının yok hükmünde olmasına neden olan ortak, hakkın kötüye kullanılması yasağı aracılığı ile menfaat temin etmiştir. Başka bir deyişle, kendi kusurundan menfaat temin etmiştir. Bunun ise hukuk düzenince korunmayacağı izahtan varestedir. $\mathrm{Bu}$ sebeplerle çalışma konumuzu oluşturan Yargıtay 11. Hukuk Dairesi'nin kararının hukuken isabetli olmadığını düşünmekteyiz. 


\section{KAYNAKÇA}

Akıntürk, Turgut (2001) Borçlar Hukuku Genel Hükümler, 8. Bası, İstanbul, Beta.

Akyol, Şener (2006) "Venire Contra Factum Proprium (Önceki Eylem ile Çelişkili Davranış Yasağı)": Ünal, Mehmet (Editör), Fikret Eren’e Armağan, Ankara, Yetkin, s. 77-96.

Antalya, Gökhan (2015) Borçlar Hukuku Genel Hükümler, C.1, Temel Kavramlar, Sözleşmeden Doğan Borç İlişkileri, İstanbul, Legal.

Antalya, Gökhan/Topuz, Murat (2015) Medeni Hukuk, İstanbul, Legal.

Aytaç, Zühtii (1982) Anonim Ortaklıklarda İbra, Ankara, Banka ve Ticaret Hukuku Araştırma Enstitüsü.

Bahtiyar, Mehmet (2020) Ortaklıklar Hukuku, 14. Baskı, İstanbul, Beta.

Bilgili, Fatih / Demirkapı, Ertan (2013) Şirketler Hukuku, 9. Baskı, Bursa, Dora.

Böckli, Peter (2009) Schweizer Aktienrecht mit Fusionsgesetz, Börsengesellschaftsrecht, Konzernrecht, Corporate Governance, Recht der Revisionsstelle und der Abschlussprüfung in neuer Fassung - unter Berücksichtigung der angelaufenen Revision des Aktien- und Rechnungslegungsrechts, 4. Auflage, Zürich, Schulthess.

Deryal, Yahya (2000) Ticaret Hukuku, 4. Bas1, Trabzon, Derya.

Domaniç, Hayri/Arslanlı, Halil (1989) Türk Ticaret Kanunu Şerhi C.III, İstanbul.

Edis, Seyfullah (1979) Medeni Hukuka Giriş ve Başlangıç Hükümleri, Ankara, Ankara Üniversitesi.

Erdoğan, Abdullah (2013) “6102 sayılı Türk Ticaret Kanunu’nun Limited Şirket Genel Kuruluna İlişkin Hükümlerinin Değerlendirilmesi”, GÜHFD, C.XVII, Y.2013, S. 3, s. 39-60.

Eren, Fikret (2019) Borçlar Hukuku Genel Hükümler, 24. Baskı, Ankara, Yetkin.

Hatemi, Hüseyin (2011) Medeni Hukuk’a Giriş, 5. Baskı, İstanbul, Vedat.

Kendigelen, Abuzer (2016) Türk Ticaret Kanunu Değişiklikler, Yenilikler, İlk Tespitler, 3. Baskı, İstanbul, Onikilevha.

Kılıçoğlu, Ahmet (2003) Borçlar Hukuku, 3. Bası, Ankara.

Kırca, İsmail/Şehirali Çelik, Feyzan Hayal/Manavgat, Çağlar (2016) Anonim Şirketler Hukuku C. 2/2, Genel Kurul Kararlarının 
Hükümsüzlügü, Ankara, Banka ve Ticaret Hukuku Araştırmaları Ensitüsü.

Kocayusupaşaoğlu, Necip/Hatemi, Hüseyin/Serozan, Rona/Arpacı, Abdulkadir (2014) Borçlar Hukuku C.1, Genel Bölüm, Borçlar Hukukuna Giriş, Hukuki İşlem, Sözleşme, 6. Baskı, İstanbul, Filiz.

Korkut, Ömer (2012) 6102 Sayılı Türk Ticaret Kanunu'na göre Anonim Şirketlerde Genel Kurul Kararlarının Butlanı, Adana, Karahan.

Moroğlu, Erdoğan (2017) Anonim Ortaklıkta Genel Kurul Kararlarının Hükümsüzlüğü, 8. Baskı, İstanbul, Onikilevha.

Narbay, Şafak (2006) “TTK Tasarısı'nda Anonim Ortaklık Genel Kurulunu Toplantıya Davete Yetkili ve Görevli Olanlara İlişkin Hükümlerin Değerlendirilmesi”, HPD 2006, S. 7, s. 168-181.

Nomer, Haluk Nami (2008) Kişi Birliklerinde Genel Kurul Kararlarının Geçersizliğine İlişkin Temel Esaslar, İstanbul, Seçkin.

Oğuzman, M. Kemal (1985) Medeni Hukuk Dersleri, 5. Bası, İstanbul.

Oğuzman, M. Kemal / Barlas, Nami (2016) Medeni Hukuk Giriş Kaynaklar Temel Kavramlar, 22. Bası, İstanbul, Vedat.

Oğuzman, M. Kemal /Öz, Turgut (2019) Borçlar Hukuku Genel Hükümler, C.1, 17. Bas1, İstanbul, Vedat.

Orbay Ortaç, Nurdan/ Al Kılıç, Şengül (2018) Anonim Şirket Yönetim Kurulu Üyelerinin ve Murahhasların Genel Kurula Katılması, TFM, 2018, C. 4, S. 2, s. 211-238.

Önder, M. Fahrettin (2005) "Yargıtay Kararları Açısından Limited Şirket Genel Kurul Kararlarının Hükümsüzlügü̈”, DEÜHFD, C. 7, S. 1, s. 103126.

Pekcanıtez, Hakan (2017), Pekcanıtez Usul Medeni Usul Hukuku, 15. Bası, İstanbul, Onikilevha.

Poroy, Reha/Tekinalp, Ünal/Camoğlu, Ersin (2014) Ortaklıklar Hukuku C. 1, 13. Bask1, İstanbul, Vedat.

Pulaşlı, Hasan (2013) “Anonim Şirket Genel Kurul Kararlarının Sakatlığı Ve Müeyyidesi”, GÜHFD, C. XVII, S. 1-2, s. 885-898.

Pulaşlı, Hasan (2017) Şirketler Hukukunun Esasları, 5. Baskı, Ankara, Adalet. Reisoğlu, Safa (2004) Borçlar Hukuku Genel Hükümler, 16. Bası, İstanbul, Beta.

Saka, Zafer (2004) Anonim Ortaklıklarda Genel Kurul, İstanbul, Vedat. 
Schott, Bertrand (2009) Aktienrechtliche Anfechtbarkeit und Nichtigkeit von Generalversammlungsbeschlüssen wegen Verfahrensmängeln, Zürich/St. Gallen, Dike.

Şener, Oruç Hami (2019) Ortaklıklar Hukuku Ders Kitabı, 4. Baskı, Ankara, Seçkin.

Tanriver, Süha (2018) Medeni Usul Hukuku Temel Kavramlar ve İlk Derece Yargilaması, C. I, Ankara, Yetkin.

Tekil, Fahiman (1981) Borçlar Hukuku, İstanbul.

Tekinalp, Ünal, "Genel Kurul Kararlarının Butlanında Anonim Ortaklığa Özgü Sebeplerin Kabulü İhtiyacı", BATIDER, C. XXV, S. 4, s. 5-16.

Tekinay, Selahattin Sulhi (1984) Medeni Hukuka Giriş Dersleri, 4. Bası, İstanbul.

Tekinay, Selahattin Sulhi/Akman, Sermet /Burcuoğlu, Haluk/Altop, Atilla (1993) Borçlar Hukuku 7. Bası, İstanbul.

Truffer, Roland/Dubs, Dieter (2012) Artikel Kommentar zu OR Art. 698706b,[içinde: Basler Kommentar Obligationenrecht II, Honsell, Heinrich / Vogt, Nedim Peter / Watter, Rolf], Basel, Helbing\&Lichtenhahn.

Turanlı, Hüsnü (2013) "Yeni Türk Ticaret Kanunu Işı̆̆ında Anonim Şirket Yönetim Kurulu Kararlarının Hükümsüzlügü”, GÜHFD, C. XVII, S. 12, s. 939-960.

von Tuhr, Andreas (1983) Borçlar Hukuku C. 1-2, , Ankara, Yargitay, (Çeviren: Edege, Cevat).

Uyar, Talih (2000) "Yargıtay Kararlarında "Dürüstlük (Objektif İyiniyet)" Kuralı (MK.2/I) ve "Hakkın Kötüye Kullanılması Yasağı" (MK.2/II)": Zafer Gören Ataysoy(Editör), Seyfullah Edis'e Armağan, İzmir, Dokuz Eylül Üniversitesi, s. 439-465.

Üçışık, Güzin/Çelik, Aydın (2013) Anonim Ortaklıklar Hukuku, C. 1, Ankara, Adalet.

Yüce, Onur Alber (2015) Anonim Şirketlerde Yönetim Kurulu Kararlarının Butlanı, 2. Baskı, İstanbul, Vedat.

Zeytin, Zafer/Ergün, Ömer (2017) Türk Medeni Hukuku, 3. Baskı, Ankara, Seçkin. 